\title{
Geochemistry of the Early Paleozoic Baiyin Volcanic Rocks (NW China): Implications for the Tectonic Evolution of the North Qilian Orogenic Belt
}

\author{
Christina Yan Wang, ${ }^{1}$ Qi Zhang, ${ }^{2}$ Qing Qian, ${ }^{2}$ and Mei-Fu Zhou ${ }^{1}$ \\ Department of Geology, Northwest University, Xi'an 710069, China \\ (e-mail: wangyan2002@hkusua.hku.hk)
}

\begin{abstract}
A B S T R A C T
The Qilian Mountains in NW China comprise the North Qilian Orogenic Belt, Central Qilian Block, and South Qilian Orogenic Belt. The North Qilian Orogenic Belt consists of the Northern and Southern terranes separated by a volcanic rock belt. This belt is composed mainly of felsic and mafic volcanic rocks. Volcanic rocks in the Baiyin area of the eastern part of the belt include rhyolites, rhyodacite, andesitic basalts, and basalts. New zircon U-Pb isotopic data yield a crystallization age of ca. $445 \mathrm{Ma}$ for the rhyolite, $30 \mathrm{~m}$.yr. younger than the associated basalts. The mafic volcanic rocks are relatively enriched in $\mathrm{Th}, \mathrm{Sr}$, and light rare earth element with $(\mathrm{La} / \mathrm{Yb})_{\mathrm{N}}$ ratios ranging from 4.2 to 5.6 and $\mathrm{La}_{\mathrm{N}}$ ranging from 40 to 49 , and depleted in high field strength elements, with high $\mathrm{Th} / \mathrm{Nb}$ ratios $(0.9-1.3)$. These features together with their $\varepsilon \mathrm{Nd}(\mathrm{T})$ values $(-1.4$ to +3.1$)$ are consistent with a subduction-related origin, most likely in a mature island arc or an arc built on thin continental crust in an active continental margin. The felsic volcanic rocks show a calc-alkaline affinity and a strong suprasubduction zone signature with negative $\mathrm{Nb}, \mathrm{Sr}$, and $\mathrm{Ti}$ anomalies and relatively high $\mathrm{Th} / \mathrm{Nb}$ ratios $(0.8-1.6)$. They have significantly high $\varepsilon \mathrm{Nd}(\mathrm{T})$ values $(+4.4$ to +7.7$)$ relative to the mafic volcanic rocks. Such radiogenic $\mathrm{Nd}$ isotopic compositions rule out a crustal origin and indicate the derivation from a depleted mantle source in a volcanic arc environment. Therefore, the geochemistry of the mafic and felsic volcanic rocks demonstrates an Ordovician volcanic arc above a northward subduction zone. The northward drifting of the Central Qilian Block eventually resulted in the amalgamation of the Northern and Southern terranes to form the North Qilian Orogenic Belt in the Early Paleozoic.
\end{abstract}

Online enhancements: tables.

\section{Introduction}

The >1000-km-long North Qilian Orogenic Belt in NW China forms the western portion of the major WNW-ESE-trending Central Orogenic Belt (Yin and Zhang 1998; Zhang and Liu 1998; fig. 1). In the eastern portion of the Central Orogenic Belt, the high-grade metamorphic rocks of the Dabie-Sulu belt have been extensively studied over the past decade (Wang and Liou 1991; Hacker et al. 1998; Cong and Wang 1999; Ye et al. 2000; Kern et al. 2002). Relatively little is known about the nature and tectonic evolution of the North Qilian Oro2004.

Manuscript received April 14, 2004; accepted September 7, ${ }^{1}$ C

${ }^{1}$ Current address: Department of Earth Sciences, University of Hong Kong, Hong Kong, China.

${ }^{2}$ Institute of Geology and Geophysics, Chinese Academy of Sciences, Beijing 100029, China. genic Belt, which is considered an orogenic belt at the northern margin of the Tibetan Plateau (Xu et al. 1999).

The North Qilian Mountains have been traditionally considered as an Early Paleozoic orogenic belt composed of two terranes separated by a volcanic rock belt. The Southern terrane is believed to be a subduction-accretionary complex (Wu et al. 1993; Song 1997; Zhang et al. 1997), whereas the Northern terrane is believed to be made up of backarc type volcanic rocks and clastic sedimentary rocks (Xu et al. 1994; fig. 1). The volcanic rock belt that lies between these two terranes consists mainly of felsic and mafic volcanic rocks, but these rocks are poorly dated, and the geodynamic significance of this belt has been debated (Xu et al. 1994; Xia et al. 1995). Xu et al. (1994) considered the vol- 


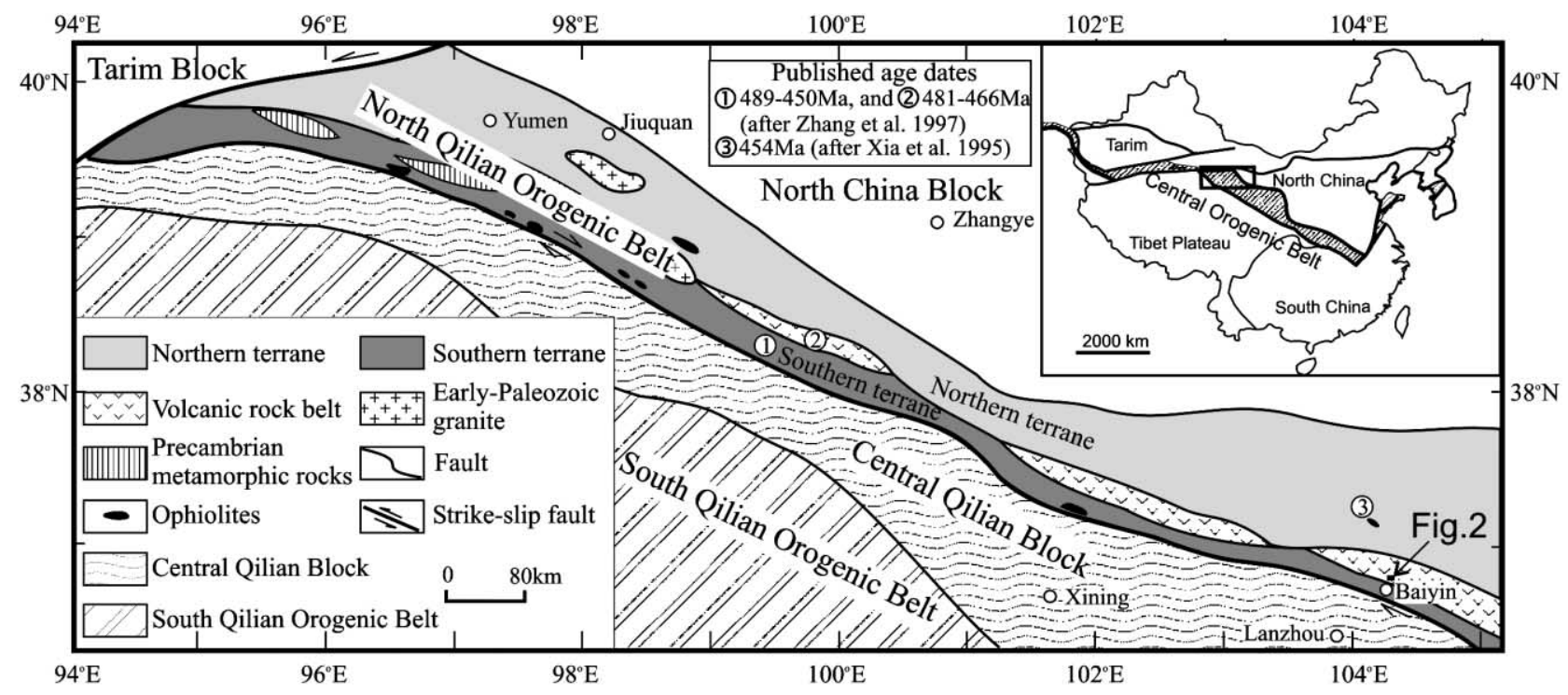

Figure 1. Simplified geological map of the North Qilian Orogenic Belt, NW China, showing the location of the Baiyin area (modified after Xu et al. 1997).

canic rock belt to represent a volcanic island arc, and the whole North Qilian Mountain is a subduction complex formed by northward subduction of the Central Qilian Block and southward accretion of the Alxa Block during 450-500 Ma. Yin and Harrison (2000) proposed a similar model in which the Northern Qilian Belt was an island arc system along the southern margin of the North China Craton but above a north-dipping subduction zone in the Ordovician. In contrast, Xia et al. (1995) interpreted the volcanic rocks as a bimodal basaltrhyolite suite formed in the Early Paleozoic in a continental rift. More detailed information is needed to constrain other possible tectonic settings for the volcanic rocks. The volcanic rocks of the Baiyin area in the eastern part of the volcanic rock belt provide an excellent opportunity for such a study because these rocks are well preserved (Peng et al. 1995; Xia et al. 1996). These rocks are also of particular interest because they host the Baiyin massive $\mathrm{Cu}-\mathrm{Pb}-\mathrm{Zn}$ sulfide deposit, the largest of its kind in China (Bian 1989; Peng et al. 1995). In this article, we report new geochronological and geochemical data for the Baiyin volcanic rocks and use these data to constrain their genesis and tectonic setting. The new data also provide new constraints on geodynamic models for the tectonic evolution of the North Qilian Orogenic Belt.

\section{Geological Background}

The Qilian Mountains form a WNW-trending belt about $300 \mathrm{~km}$ wide and $1200 \mathrm{~km}$ long that straddles the boundary between Qinghai Province and Gansu Province in NW China. Traditionally, the belt has been divided into the North Qilian Orogenic Belt, Central Qilian Block, and South Qilian Orogenic Belt (fig. 1). Two terranes are recognized in the North Qilian Orogenic Belt (Zhang et al. 1997), a Southern and Northern terrane separated by a volcanic rock belt (fig. 1). The Southern terrane is a subduction-accretionary complex of ophiolites, blueschists, C-type eclogites, phengite schists, and abyssal and bathyal sedimentary rocks (Xu et al. 1994). The Northern terrane consists of mafic lavas, pyroclastic rocks, clastic sedimentary rocks, and minor ophiolites formed in a back-arc basin environment (Xu et al. 1994). The 1000-km-long volcanic rock belt consists of both mafic and felsic volcanic rocks that have long been recognized to have similar origin (Xia et al. 1996). In the Baiyin area, the volcanic rocks crop out over an area of about $40 \mathrm{~km}^{2}$ and are comprised predominantly of felsic volcanic rocks and minor mafic volcanic rocks. The volcanic rocks occur as deformed tectonic slices, separated by WNW-trending ductile shear zones along which the rocks have been mylonitized (fig. 2). Most of the rocks have a penetrative foliation that strikes $120^{\circ}-130^{\circ}$ and dips $50^{\circ}-$ $70^{\circ} \mathrm{S}$. These structural orientations have been produced by Cenozoic thrusting on the northern margin of the Qilian Mountain (Tapponnier et al. 1990). The volcanic rocks are unconformably overlain by a metasedimentary sequence composed chiefly of phyllite and marble with some interca- 


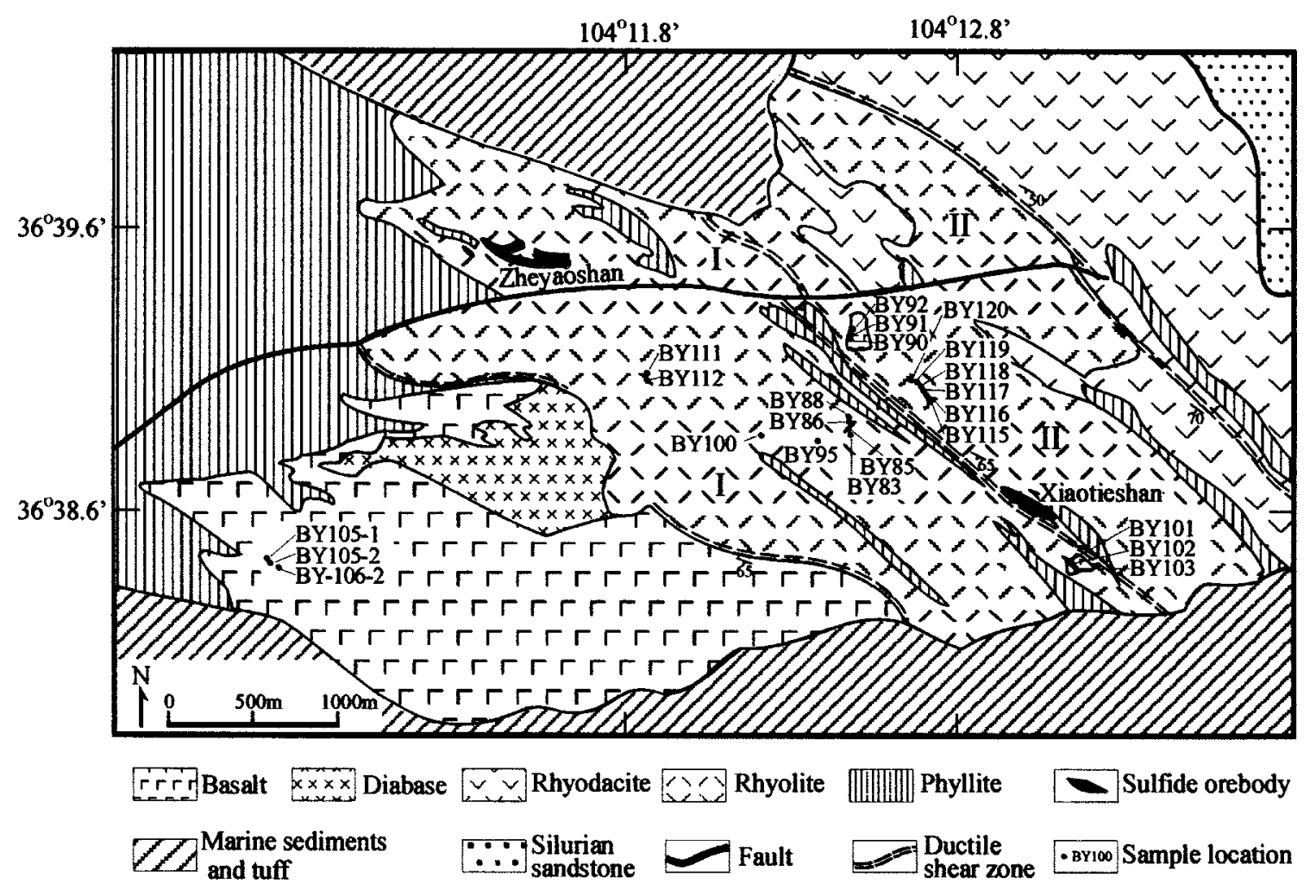

Figure 2. Geological map of the Baiyin area showing the major massive sulfide deposits hosted in felsic volcanic rocks in the Zheyaoshan and Xiaotieshan areas (modified after unpublished $1: 25,000$ geological map of the Baiyin area, 1989, by the Baiyin Geological Survey Group).

lated beds of Fe-Mn nodules and carbonaceous shale. The age of the volcanic rocks is uncertain; previous $\mathrm{Sm}-\mathrm{Nd}$ and $\mathrm{Rb}-\mathrm{Sr}$ isochron ages of the rocks range from $1292 \pm 69 \mathrm{Ma}$ to $522 \pm 44 \mathrm{Ma}$ for the mafic volcanic rocks and $606 \pm 3 \mathrm{Ma}$ for the felsic volcanic rocks (Xia et al. 1996 and references therein).

The felsic volcanic rocks host the Xiaotieshan massive $\mathrm{Pb}-\mathrm{Zn}-\mathrm{Cu}$ sulfide deposits and the Zheyaoshan $\mathrm{Cu}-\mathrm{Zn}$ sulfide deposits (fig. 2). In the Xiaotieshan area, the host rocks include rhyolitic and rhyodacitic rocks interbedded with phyllite and schist. Minor mafic volcanic rocks occur as xenoliths in the felsic volcanic rocks. The rocks in the Zheyaoshan area are felsic and mafic volcanic rocks. Overall, the Baiyin volcanic rocks comprise breccia, tuff, and lava. The ratio of lavas to pyroclasts in the mafic volcanic rocks is close to $1: 1$, indicating the explosive index is close to $50 \%$, whereas the ratio in the felsic volcanic rocks is $1: 5$ and $1: 19$ in the Zheyaoshan and Xiaotieshan areas, respectively, indicating a very high explosive index $(>60 \%$ for the Zheyaoshan area, $>80 \%$ for the Xiaotieshan area). However, about $75 \%$ of rhyo- dacitic rocks are lavas, indicating a low explosive index.

All the volcanic rocks have been metamorphosed under greenschist facies condition. The primary minerals of the mafic volcanic rocks have been completely replaced by albite, actinolite, chlorite, epidote, titanite, and hematite. The felsic lavas are sparsely phyric with a few phenocrysts of albite and quartz set in a felsic matrix containing sericite as well as sparse chlorite, epidote, and zoisite and accessory pyrite, hematite, zircon, and apatite.

\section{Analytical Methods}

Zircon U-Pb Isotopic Ages. Both thermal ionization mass spectrometry (TIMS) and sensitive highresolution ion microprobe (SHRIMP) were used for zircon $\mathrm{U}-\mathrm{Pb}$ isotopic analyses. The TIMS U-Pb isotopic analyses were carried out on a VG-354 mass spectrometer in the Institute of Geology and Geophysics, Chinese Academy of Sciences, Beijing. Only those crystals that were nonmagnetic on a Frantz Isodynamic Separator and contained a minimum of visible imperfections were selected for analysis. The 
Table 1. U-Pb Thermal Ionization Mass Spectrometry (TIMS) Analytical Results of Zircons from the Felsic and Mafic Volcanic Rocks from the Baiyin Area, NW China

\begin{tabular}{|c|c|c|c|c|c|c|c|c|c|c|c|c|}
\hline \multirow[b]{2}{*}{ Fraction $(\mu \mathrm{m})$} & \multirow[b]{2}{*}{$\begin{array}{l}\text { Zircon } \\
\text { grains }\end{array}$} & \multirow[b]{2}{*}{$\begin{array}{c}\mathrm{U} \\
(\mathrm{pmol})\end{array}$} & \multirow[b]{2}{*}{$\begin{array}{c}\mathrm{Pb} \\
(\mathrm{pmol})\end{array}$} & \multicolumn{3}{|c|}{$\mathrm{Pb}$ isotope composition } & \multicolumn{3}{|c|}{ Atomic ratios } & \multicolumn{3}{|c|}{ Apparent ages (Ma) } \\
\hline & & & & $\frac{{ }^{206} \mathrm{~Pb}}{{ }^{204} \mathrm{~Pb}}$ & $\frac{{ }^{207} \mathrm{~Pb}}{{ }^{204} \mathrm{~Pb}}$ & $\frac{{ }^{208} \mathrm{~Pb}}{{ }^{204} \mathrm{~Pb}}$ & $\frac{{ }^{206} \mathrm{~Pb}}{{ }^{238} \mathrm{U}}$ & $\frac{{ }^{207} \mathrm{~Pb}}{{ }^{235} \mathrm{U}}$ & $\frac{{ }^{207} \mathrm{~Pb}}{206 \mathrm{~Pb}}$ & $\frac{{ }^{206} \mathrm{~Pb}}{{ }^{238} \mathrm{U}}$ & $\frac{{ }^{207} \mathrm{~Pb}}{{ }^{235} \mathrm{U}}$ & $\frac{{ }^{207} \mathrm{~Pb}}{{ }^{206} \mathrm{~Pb}}$ \\
\hline \multicolumn{13}{|c|}{$\begin{array}{l}\text { Felsic volcanic rock } \\
\text { (sample BY86): }\end{array}$} \\
\hline $1>100$ & 49 & 71.62 & 7.68 & 361 & 34 & 95 & .0752 & .5761 & .0556 & 467.4 & 461.9 & 430.0 \\
\hline $2<80$ & 59 & 66.20 & 8.43 & 510 & 43 & 117 & .0936 & .7358 & .0570 & 576.9 & 559.9 & 492.5 \\
\hline $3<100$ & 63 & 61.64 & 5.66 & 357 & 32 & 89 & .0650 & .4608 & .0515 & 405.9 & 384.8 & 265.0 \\
\hline $4>100$ & 45 & 104.81 & 10.07 & 493 & 42 & 113 & .0705 & .5460 & .0562 & 439.5 & 442.4 & 456.3 \\
\hline \multicolumn{13}{|c|}{$\begin{array}{l}\text { Mafic volcanic rock } \\
\text { (sample BY105-1): }\end{array}$} \\
\hline $1<100$ (zircon) & 45 & 28.80 & 3.53 & 298 & 30 & 109 & .0781 & .5811 & .0540 & 484.8 & 465.2 & 369.4 \\
\hline $2<200$ (sphene) & 60 & 22.25 & 2.83 & 111 & 20 & 58 & .0625 & .4494 & .0522 & 390.8 & 376.9 & 291.9 \\
\hline
\end{tabular}

Note. $\mathrm{Pb}$ blanks were corrected using the following isotopic composition: ${ }^{204} \mathrm{~Pb}_{\mathrm{o}} 1.4010,{ }^{206} \mathrm{~Pb}_{\mathrm{o}} 25.1480,{ }^{207} \mathrm{~Pb}_{\mathrm{o}}{ }^{22.0658}$, and ${ }^{208} \mathrm{~Pb}_{\mathrm{o}}$ 51.3887. For the felsic volcanic rocks sample, initial common lead correction used the isotope composition determined by us for the closely associated massive sulfide deposits $\left({ }^{206} \mathrm{~Pb} /{ }^{204} \mathrm{~Pb} 17.968,{ }^{207} \mathrm{~Pb} /{ }^{204} \mathrm{~Pb} 15.595,{ }^{208} \mathrm{~Pb} /{ }^{204} \mathrm{~Pb} 37.802\right)$. For the mafic volcanic rocks sample, nonradiogenic lead not accounted for by the blank (initial common lead) was corrected for using the Stacey and Kramers (1975) growth model. Individual fraction errors $(2 \sigma)$ are $<2 \%$.

grains were digested following the technique of Krogh (1973). Total procedural blanks for these analyses were $10 \mathrm{pg}$ for $\mathrm{Pb}$ and $<2 \mathrm{pg}$ for $\mathrm{U}$.

The SHRIMP U-Pb isotopic analyses were performed on a SHRIMP II in the Institute of Geology, Chinese Academy of Geosciences, Beijing. Zircon samples were mounted in epoxy and ground to approximately half their thickness to expose their centers. A piece of RSES (Research School of Earth Science at the Australian National University) reference zircon SL13 and several grains of the Temora standard (TEM; see Black et al. 2003) were also prepared in a separate mount. Details of the analytical procedure are given by Compston et al. (1992) and Williams and Claesson (1987). Interelement fractionation in ion emission of zircon was corrected relative to the RSES references, using SL13 (572 Ma, $238 \mathrm{ppm}$ ) for the initial calibration and TEM (417 $\mathrm{Ma})$ for the final calibration. The reproducibility based on the TEM standard was about $2 \%$. The software of Ludwig SQUID 1.0 (Ludwig 2001) and attached ISOPLOT were used for data processing. The correction for initial lead (from ${ }^{204} \mathrm{~Pb}$ ) was made using the $\mathrm{Pb}$ composition (Stacey and Kramers 1975). Uncertainties in ages are cited as $1 \sigma$, and the weighted average mean ages are quoted at $95 \%$ confidence limits.

Major and Trace Element Determination. Samples for chemical analysis were collected far away from the massive sulfide deposits, and fine calcite veins were removed before the samples were crushed in an agate mill. Abundances of major elements were determined by x-ray fluorescence spectrometry (XRF) on fused glass pellets at the National Taiwan University. All trace element data, including the rare earth elements (REE), were analyzed on a PE Elan 6000 Inductively Coupled Plasma Mass Spectrometer (ICP-MS) at Guangzhou Institute of Geochem- istry, Chinese Academy of Sciences. Sample powders were digested following the protocol of Qi et al. (2000) for ICP-MS analyses. Pure elemental standards were used for external calibration, and BHVO1 and BCR-1 as a reference material. Accuracies of the XRF analyses are estimated as $\pm 1 \%$ for major elements present in concentrations greater than 0.5 wt $\%$. The ICP-MS analyses yield accuracy better than $\pm 10 \%$ and precision normally less than $3 \%$.

Sr and Nd Isotopic Analyses. Twelve samples of the Baiyin volcanic rocks were analyzed for Sr and $\mathrm{Nd}$ isotope compositions using a Finnigan-MAT 261 mass spectrometer at the Institute of Geology, Chinese Academy of Geosciences, Beijing. The measured values for the J.M. Nd standard were ${ }^{143} \mathrm{Nd} /{ }^{144} \mathrm{Nd}=0.511125 \pm 8(2 \sigma)$ and the BCR-1 Nd standard gave ${ }^{143} \mathrm{Nd} /{ }^{144} \mathrm{Nd}=0.512643 \pm 12(2 \sigma)$. The measured value for the National Bureau of Standard (NBS) $987 \mathrm{Sr}$ standard was ${ }^{87} \mathrm{Sr} /{ }^{86} \mathrm{Sr}=$ $0.710250 \pm 2(2 \sigma)$.

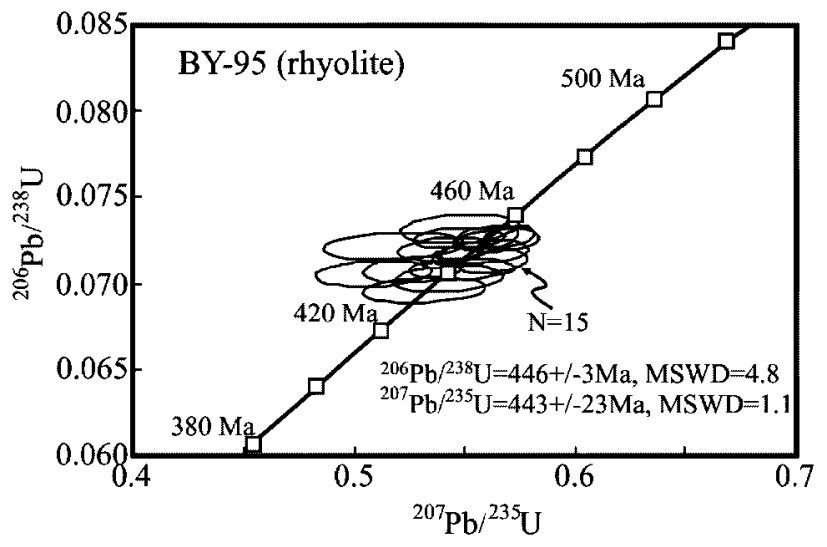

Figure 3. Zircon U-Pb concordia plot for the Baiyin felsic volcanic rocks (sample BY95), NW China. 


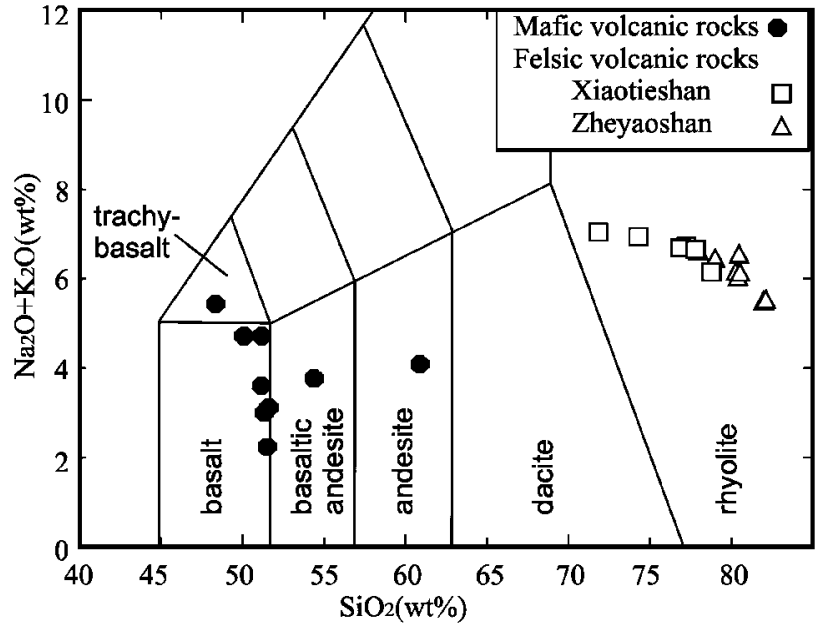

Figure 4. Total alkalis $\left(\mathrm{Na}_{2} \mathrm{O}+\mathrm{K}_{2} \mathrm{O}\right)$ versus $\mathrm{SiO}_{2}$ plot of the Baiyin volcanic rocks, NW China (reference fields are from Le Maitre 1989).

\section{Analytical Results}

Zircon U-Pb Geochronology. We tried to separate zircon grains from the mafic and felsic volcanic rocks in the Zheyaoshan area and the felsic volcanic rocks in the Xiaotieshan area. However, our attempt was not successful, because the zircons in the Xiaotieshan felsic volcanic rocks are too small to be analyzed. Consequently, we were restricted to analyze zircons from the mafic and felsic volcanic rocks in the Zheyaoshan area.

Most zircons separated from the volcanic rocks are euhedral and prismatic and are about $80-120$ $\mu \mathrm{m}$ long with length/width ratios between $3: 1$ and $5: 1$. Some anhedral grains are about $70 \times 50 \mu \mathrm{m}$ across. The grains are light brown and translucent with rare thin dark inclusions or with elongate apatite and titanite inclusions.

The TIMS results for the zircons from samples BY105-1 (basalt) and BY86 (rhyolite) in the Zheyaoshan area are listed in table 1. Two fractions (the second and third fraction) yield ages above the Concordia, which may result from incomplete digestion of the zircons in the bombs. However, the other two fractions (the first and fourth fraction) of the zircons from the rhyolite on the Concordia yield an average ${ }^{206} \mathrm{~Pb} /{ }^{238} \mathrm{U}$ age of $453 \pm 12 \mathrm{Ma}$. The average of ${ }^{206} \mathrm{~Pb} /{ }^{238} \mathrm{U}$ and ${ }^{207} \mathrm{~Pb} /{ }^{235} \mathrm{U}$ age of the zircons from the basalt is $475 \pm 10 \mathrm{Ma}$, which is considered to be the crystallization age.

The SHRIMP analytical results for a rhyolite sample (BY95) in the Zheyaoshan area are listed in table 2 (available in the online edition of the Journal of Geology and also from the Journal's Data De- pository in the Journal of Geology office upon request). All analyses (15 spots on 15 grains) have Th/ $\mathrm{U}$ ratios of $0.35-0.78$ and yield a weighted average ${ }^{206} \mathrm{~Pb} /{ }^{238} \mathrm{U}$ age of $446 \pm 3 \mathrm{Ma}$ and ${ }^{207} \mathrm{~Pb} /{ }^{206} \mathrm{~Pb}$ age of $443 \pm 24 \mathrm{Ma}$ (fig. 3). The ${ }^{206} \mathrm{~Pb} /{ }^{238} \mathrm{U}$ age of $446 \pm$ $3 \mathrm{Ma}$ is considered to be the crystallization age of the rhyolite and is consistent with the TIMS age within analytical uncertainty.

Major Oxides and Trace Elements. The major and trace element compositions of the Baiyin volcanic rocks are given in table 3 (available in the online edition of the Journal of Geology and also from the Journal's Data Depository in the Journal of Geology office upon request). Among them, samples from BY90 to BY92 and from BY101 to BY103 are mafic volcanic xenoliths enclosed within the Xiaotieshan and Zheyaoshan felsic volcanic rocks, BY105-1 to BY106-2 are mafic volcanic rocks at Zheyaoshan, samples from BY83 to BY112 are felsic volcanic rocks at Zheyaoshan, and samples from BY115 to BY120 are felsic volcanic rocks at Xiaotieshan. Although the samples are altered, most of them do not show large $(>4 \mathrm{wt} \%)$ losses on ignition nor evidence which might suggest any significant mobility of the light rare earth element (LREE; e.g., Ce anomalies). Therefore, we believe that the $\varepsilon \mathrm{Nd}(\mathrm{T})$ values and the reported values of high field strength elements (HFSE; such as $\mathrm{Nb}, \mathrm{Ta}$, and Ti), REE, and Th in this study reflect those of the original magmatic rocks.

The mafic volcanic rocks are chiefly basaltic rocks with minor trachy-basalts and andesites (fig.

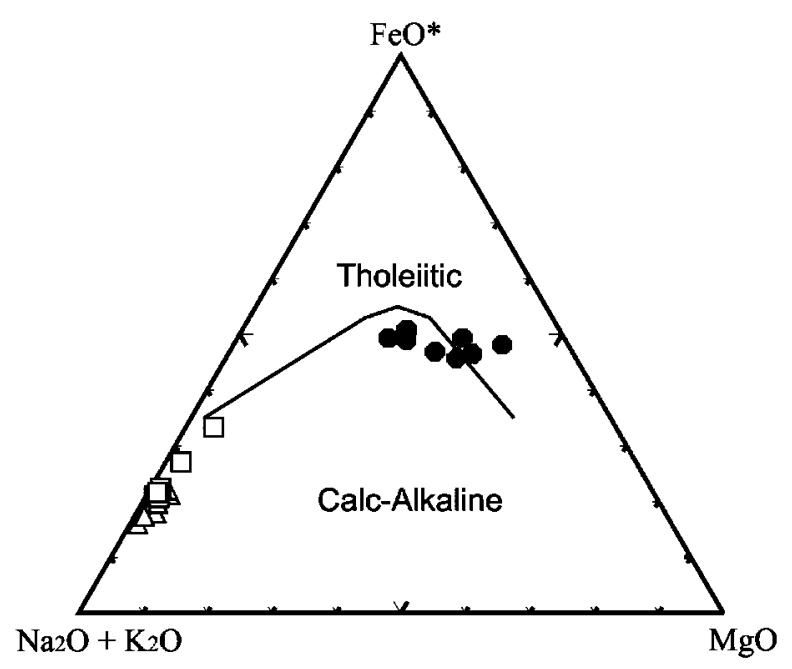

Figure 5. AFM $\left(\left[\mathrm{Na}_{2} \mathrm{O}+\mathrm{K}_{2} \mathrm{O}\right]-\mathrm{FeO}^{*}-\mathrm{MgO}\right)$ plot of the Baiyin volcanic rocks, NW China (reference fields after Irvine and Baragar 1971). Symbols are the same as those for figure 4. 


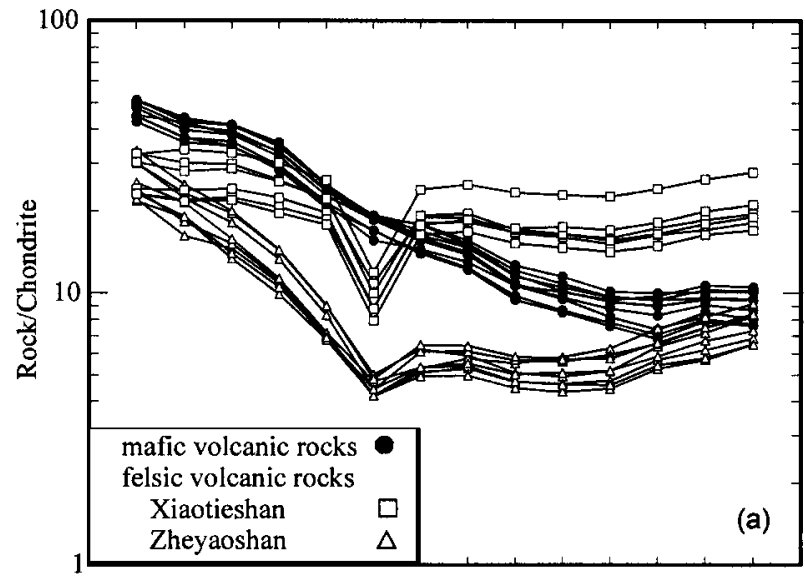

La Ce Pr Nd Sm Eu Gd Tb Dy Ho Er Tm Yb Lu

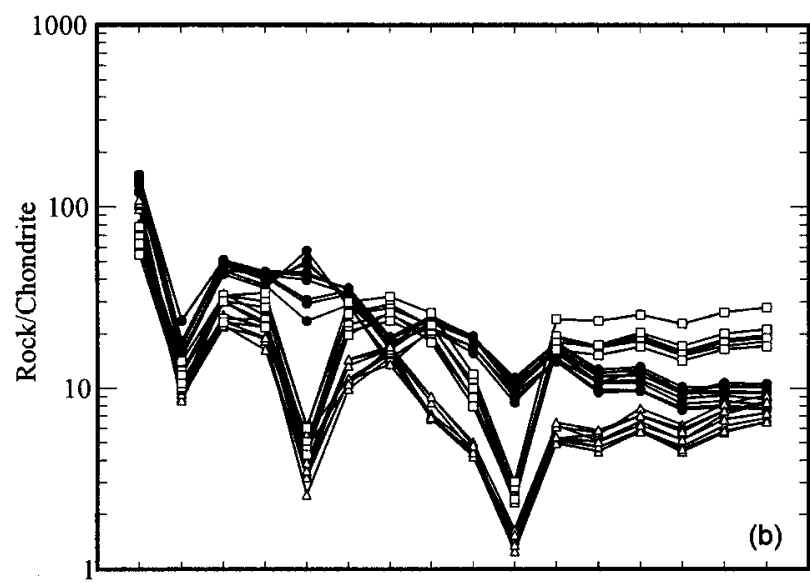

Th Nb La Ce Sr Nd Zr Sm Eu Ti Gd Dy Y Er Yb Lu

Figure 6. Chondrite-normalized rare earth element patterns $(a)$ and chondrite-normalized trace element patterns $(b)$ for the Baiyin volcanic rocks, NW China. Normalization values are from Nakamura (1974) and Sun (1980), respectively. Trace element pattern is after Thompson (1982).

4). The mafic rocks exhibit a calc-alkaline trend in the AFM diagram (fig. 5). Total alkalis $\left(\mathrm{Na}_{2} \mathrm{O}+\right.$ $\mathrm{K}_{2} \mathrm{O}$ ) covary positively with $\mathrm{SiO}_{2}$, but $\mathrm{FeO}^{*} / \mathrm{MgO}$ ratios are relatively constant. None of the analyzed mafic volcanic rocks reflects primary magma compositions. The highest Ni concentration is $42 \mathrm{ppm}$ and $\mathrm{Mg}$ numbers $\left(100 \mathrm{Mg} /\left[\mathrm{Mg}+\mathrm{Fe}^{2+}\right]\right)$ range from 43 to 58 , substantially lower than values expected for magmas that last equilibrated with peridotite in the upper mantle (Wilson 1989). These are clearly evolved mafic volcanic rocks that experienced fractionation of olivine, possibly accompanied by augite and/or plagioclase. All mafic volcanic rocks have chondrite-normalized REE patterns enriched in LREE with $(\mathrm{La} / \mathrm{Yb})_{\mathrm{N}}$ ratios ranging from 4.2 to 5.6 and $\mathrm{La}_{\mathrm{N}}$ ranging from 40 to
49 (fig. 6a). They are characterized by much higher $\mathrm{Th} / \mathrm{Nb}(0.8-1.3)$, Th/La $(0.4-0.5)$, and $\mathrm{La} / \mathrm{Nb}(2.0-$ 2.9) ratios, and a lower $\mathrm{Zr} / \mathrm{Nb}(13-20)$ ratio than normal mid-ocean ridge basalt (N-MORB; 0.071, $0.067,1.07$, and 30, respectively; Weaver 1991). On the $\mathrm{Th} / \mathrm{Nb}$ versus $\mathrm{Ce} / \mathrm{Nb}$ diagram (fig. 7), the mafic volcanic rocks have the $\mathrm{Th} / \mathrm{Nb}$ ratios close to arcrelated rocks and subduction-related sediment composition, far away from the upper continental crust composition.

The felsic volcanic rocks also show a calcalkaline affinity on the AFM diagram (fig. 5) and a strong suprasubduction zone signature with negative $\mathrm{Nb}, \mathrm{Sr}, \mathrm{Ti}$ anomalies (fig. $6 b$ ) and relatively high $\mathrm{Th} / \mathrm{Nb}$ ratios (Xiaotieshan, 0.8-0.9; Zheyaoshan, 1.4-1.6). However, the felsic volcanic rocks at the Xiaotieshan have a somewhat different geochemistry from those in the Zheyaoshan area, particularly in their trace element contents. For example, HFSE, such as $\mathrm{Zr}, \mathrm{Nb}, \mathrm{Ti}, \mathrm{P}, \mathrm{Hf}$, and $\mathrm{Y}$, are consistently higher in the Xiaotieshan felsic volcanic rocks than in those from Zheyaoshan (table 3 ). On the other hand, the Zheyaoshan felsic volcanic rocks are relatively enriched in LREEs, with $\mathrm{La}_{\mathrm{N}} / \mathrm{Yb}_{\mathrm{N}}=2.7-4.4$ and $\mathrm{Yb}_{\mathrm{N}}=5.7-8.2$, giving a Ushaped pattern, whereas the Xiaotieshan felsic volcanic rocks have flat chondrite-normalized REE

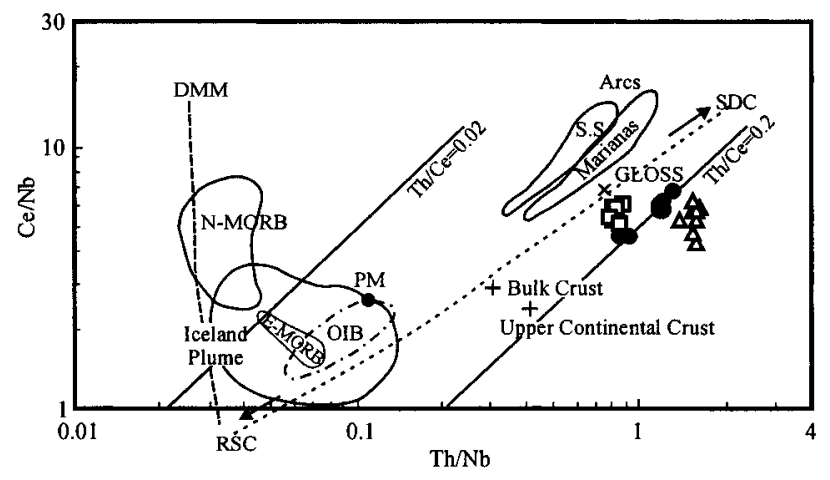

Figure 7. Plot of $\mathrm{Th} / \mathrm{Nb}$ versus $\mathrm{Ce} / \mathrm{Nb}$ for the Baiyin volcanic rocks. $D M M=$ depleted mantle; $E-M O R B=$ enriched mid-ocean ridge basalt; $N-M O R B=$ normal mid-ocean ridge basalt; $O I B=$ oceanic island basalt; $P M=$ primitive mantle; $R S C=$ recycled residual slab composition; $S D C=$ recycled subduction-derived component. The compositions of upper continental crust and bulk continental crust are from Saunders et al. (1988, 1991). Data for Iceland plume are from Hemond et al. (1993). Fields for arcs are from Saunders et al. (1991). Global subducting sediment composition (GLOSS) is after Plank and Langmuir (1998). Symbols are the same as those for figure 6 . 
Table 4. Sm-Nd and Rb-Sr Isotopic Compositions of the Baiyin Volcanic Rocks, NW China

\begin{tabular}{|c|c|c|c|c|c|c|c|c|c|c|c|}
\hline Samples & $\mathrm{Rb}$ & $\mathrm{Sr}$ & $\frac{{ }^{87} \mathrm{Rb}}{{ }^{86} \mathrm{Sr}}$ & ${ }^{87} \mathrm{Sr} /{ }^{86} \mathrm{Sr}$ & $\left({ }^{87} \mathrm{Sr} /{ }^{86} \mathrm{Sr}\right)_{i}$ & $\mathrm{Sm}$ & $\mathrm{Nd}$ & $\frac{{ }^{147} \mathrm{Sm}}{{ }^{144} \mathrm{Nd}}$ & ${ }^{143} \mathrm{Nd} /{ }^{144} \mathrm{Nd}$ & $\left(\frac{{ }^{143} \mathrm{Nd}}{{ }^{144} \mathrm{Nd}}\right)_{\mathrm{i}}$ & $\varepsilon \mathrm{Nd}(\mathrm{T})$ \\
\hline \multicolumn{12}{|c|}{ Mafic volcanic rocks: } \\
\hline BY90 & .20 & 231.8 & .003 & $.706737 \pm 15$ & .7067 & 3.78 & 16.43 & .1391 & $.512399 \pm 11$ & .5120 & -1.4 \\
\hline BY101 & 1.40 & 290.5 & .014 & $.706453 \pm 14$ & .7064 & 4.08 & 18.02 & .1370 & $.512455 \pm 8$ & .5121 & -.2 \\
\hline BY102 & .29 & 307.3 & .003 & $.706618 \pm 13$ & .7066 & 4.33 & 19.02 & .1378 & $.512485 \pm 6$ & .5121 & +.4 \\
\hline BY105-1 & 19.4 & 398.9 & .14 & $.707354 \pm 12$ & .7065 & 3.68 & 18.42 & .1209 & $.512577 \pm 9$ & .5122 & +3.1 \\
\hline BY106-1 & 73.4 & 436.1 & .49 & $.709626 \pm 11$ & .7065 & 4.38 & 19.21 & .1380 & $.512560 \pm 8$ & .5122 & +1.8 \\
\hline \multicolumn{12}{|c|}{$\begin{array}{l}\text { Felsic volcanic rocks } \\
\text { (Zheyaoshan): }\end{array}$} \\
\hline BY85 & 11.2 & 28.91 & 1.13 & $.713015 \pm 17$ & .7059 & 1.3 & 6.21 & .1267 & $.512696 \pm 12$ & .5123 & +5.1 \\
\hline BY88 & 6.41 & 35.11 & .53 & $.709395 \pm 13$ & .7061 & 1.33 & 6.7 & .1197 & $.512652 \pm 8$ & .5123 & +4.6 \\
\hline BY95 & 27.1 & 61.58 & 1.28 & $.713428 \pm 15$ & .7054 & 1.38 & 6.67 & .1254 & $.512654 \pm 6$ & .5123 & +4.4 \\
\hline BY111 & 14.3 & 37.93 & 1.09 & $.712506 \pm 13$ & .7056 & 1.54 & 7.87 & .1183 & $.512636 \pm 9$ & .5123 & +4.4 \\
\hline \multicolumn{12}{|c|}{$\begin{array}{l}\text { Felsic volcanic rocks } \\
\text { (Xiaotieshan): }\end{array}$} \\
\hline BY116 & 39.6 & 77.88 & 1.47 & $.715275 \pm 14$ & .7060 & 5.0 & 17.76 & .1702 & $.512870 \pm 6$ & .5124 & +6.0 \\
\hline BY118 & 6.98 & 54.68 & .37 & $.706940 \pm 16$ & .7046 & 4.23 & 15.49 & .1652 & $.512940 \pm 8$ & .5125 & +7.7 \\
\hline BY120 & 3.94 & 45.36 & .25 & $.707496 \pm 14$ & .7059 & 3.46 & 11.86 & .1765 & $.512930 \pm 5$ & .5124 & +6.8 \\
\hline
\end{tabular}

Note. $\quad \lambda\left({ }^{87} \mathrm{Rb}\right)=1.42 \times 10^{-11} \mathrm{y}^{-1}, \lambda\left({ }^{147} \mathrm{Sm}\right)=6.54 \times 10^{-12} \mathrm{y}^{-1}$. The $\varepsilon$ values were calculated relative to present-day chondrite values of ${ }^{143} \mathrm{Nd} /{ }^{144} \mathrm{Nd}=0.512638,{ }^{147} \mathrm{Sm} /{ }^{144} \mathrm{Nd}=0.1967,{ }^{87} \mathrm{Sr} /{ }^{86} \mathrm{Sr}=0.7045$, and ${ }^{87} \mathrm{Rb} /{ }^{86} \mathrm{Sr}=0.0827$. Initial ratios were calculated assuming age at $445 \mathrm{Ma}$.

patterns with $\mathrm{La}_{\mathrm{N}} / \mathrm{Yb}_{\mathrm{N}}=1.2-1.9$ and $\mathrm{Yb}_{\mathrm{N}}=$ 16-26 (fig. 6a).

Sm-Nd and Rb-Sr Isotopic Compositions. The Sm$\mathrm{Nd}$ and $\mathrm{Rb}-\mathrm{Sr}$ isotopic data are listed in table 4 . The mafic and felsic volcanic rocks define an array that falls near the "mantle correlation line" but is distinctly displaced to the right (fig. 8), indicating a seawater contribution of $\mathrm{Sr}$ accompanying alteration. Alteration can be observed in thin sections and is manifested in the relatively high loss on ignition in some samples ( $>4 \mathrm{wt} \%$ ).

The isotope ratio data indicate a clear difference between mafic and felsic volcanic rocks. The mafic volcanic rocks have $\left({ }^{87} \mathrm{Sr} /{ }^{86} \mathrm{Sr}\right)_{\mathrm{i}}$ ratios between 0.7064 and 0.7067 and $\varepsilon \mathrm{Nd}(\mathrm{T})$ values between -1.4 and +3.1 . The Zheyaoshan felsic volcanic rocks have $\left({ }^{87} \mathrm{Sr} /{ }^{86} \mathrm{Sr}\right)_{\mathrm{i}}$ ratios between 0.7054 and 0.7061 and $\varepsilon \mathrm{Nd}(\mathrm{T})$ values between +4.4 and +5.1 , whereas those from Xiaotieshan have $\left({ }^{87} \mathrm{Sr} /{ }^{86} \mathrm{Sr}\right)_{\mathrm{i}}$ ratios between 0.7046 and 0.7060 and $\varepsilon \mathrm{Nd}(\mathrm{T})$ values between +6.0 and +7.7 (table 4$)$. The $\left({ }^{87} \mathrm{Sr} /{ }^{86} \mathrm{Sr}\right)_{\mathrm{i}}$ ratios of the mafic volcanic rocks correlate negatively with the $\varepsilon \mathrm{Nd}(\mathrm{T})$ values. The mafic volcanic rocks plot far from depleted mantle (DM) compositions and show a trend toward Enriched Mantle II (EM II; Zindler and Hart 1986; fig. 8). However, the felsic volcanic rocks have high positive $\varepsilon \mathrm{Nd}(\mathrm{T})$ values relative to the mafic volcanic rocks and show a trend toward DM (fig. 8), indicating that the rhyolitic magmas formed by partial melting of mafic rocks from a depleted source rather than from anatexis of continental crust.

\section{Discussion}

Arc-Related Origin of the Baiyin Volcanic Rocks. Unlike basalts in continental rifts, which often show tholeiitic or alkaline trends with high $\mathrm{Ti}$ $\left(\mathrm{TiO}_{2}>2 \mathrm{wt} \%\right)$, enrichment of HFSE and strongly differentiated LREE/heavy rare earth element

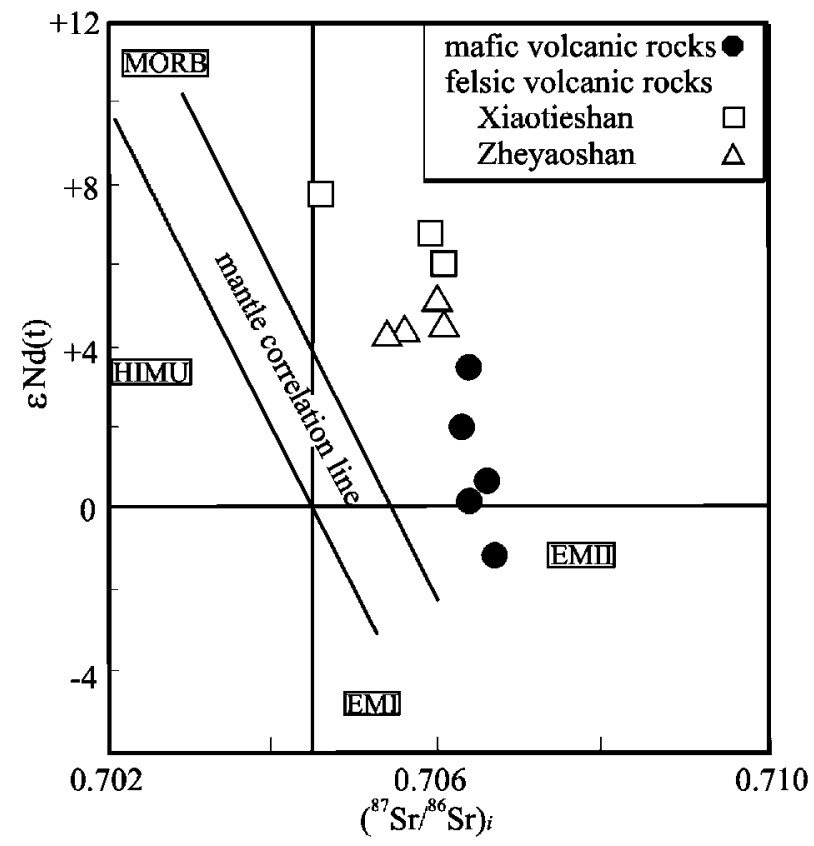

Figure 8. Initial Sr-Nd isotopic compositions of the Baiyin volcanic rocks, NW China. 


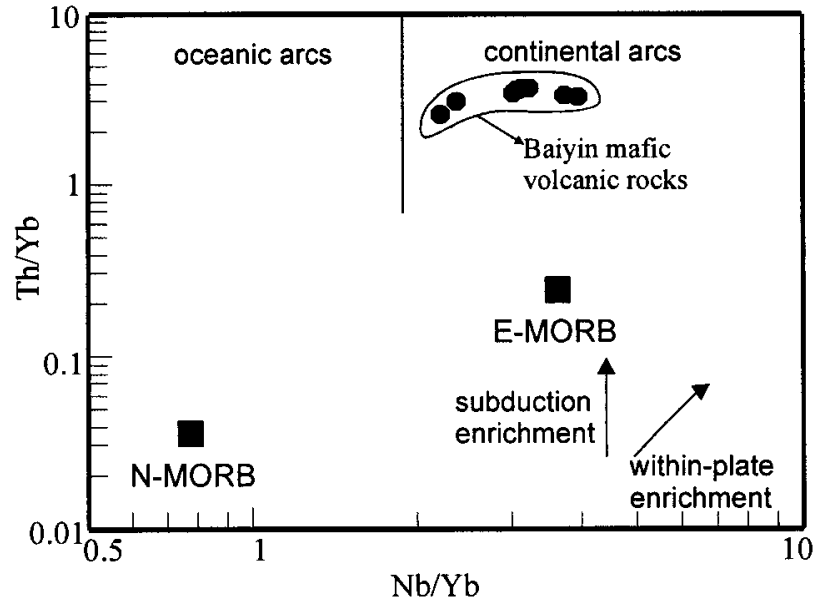

Figure 9. Plot of $\mathrm{Nb} / \mathrm{Yb}$ versus $\mathrm{Th} / \mathrm{Yb}$ for the Baiyin mafic volcanic rocks, NW China (reference fields are after Dunphy and Ludden 1998). Normal mid-ocean ridge basalt $(N-M O R B)$ and enriched mid-ocean ridge basalt $(E-$ $M O R B$ ) values after Sun and McDonough (1989).

(HREE) patterns (Hildreth et al. 1991), the Baiyin mafic volcanic rocks have low $\mathrm{Ti}$, high $\mathrm{Al}$, and moderate LREE enrichment. All of the analyzed samples show pronounced negative $\mathrm{Nb}$ anomalies, which is inconsistent with a continental rift. Much has been made of $\mathrm{Zr} / \mathrm{Nb}$ in basic rocks from different tectonic settings (Pearce and Norry 1979). The ratio changes from 40 in N-MORB, to 10 in enriched-MORB (E-MORB), to $<10$ in oceanic island basalt $(\mathrm{OIB})$ rocks and rift-related settings (Africa's Western Rift; 2 ; Pearce and Norry 1979). Therefore, the Baiyin mafic volcanic rocks are not related to a rift setting. Moreover, the Baiyin mafic volcanic rocks have $\varepsilon \mathrm{Nd}(\mathrm{T})$ values less than +4 and $\mathrm{Yb}_{\mathrm{N}}$ between 7 and 10, indicating a weakly depleted mantle source. Initial $\mathrm{Sr}$ and $\mathrm{Nd}$ isotopic compositions further indicate that the mantle source is mixed with EM II material (fig. 8). Such an enriched component with an EM II isotopic composition could represent subducted pelagic sediments, slabderived fluids, subcontinental lithosphere, continental crust, or a combination of any of these materials (Hofmann and White 1982; Cousens et al. 1994). However, the Baiyin mafic volcanic rocks display higher $\mathrm{Th} / \mathrm{Nb}$ ratios (average 1.1) than continental crust (0.44; Weaver 1991), but close to the global subducting sediment composition (GLOSS; 0.77; after Plank and Langmuir 1998). Thus, the Th enrichment and $\mathrm{Nb}$ depletion of the Baiyin mafic volcanic rocks are interpreted as features associated with slab-derived fluids or sediments rather than continental crustal contamination. Relatively, en- richment of Th, enrichment or depletion of Sr, and depletion of HFSE (fig. 6b) are characteristic of suprasubduction zone magmas.

Subduction-related environments can be intraoceanic arcs, incipient back-arc basins, mature arcs, or active continental margins. Basalts in intraoceanic arcs are often low-K tholeiites with chondrite-normalized LREE patterns that range from strongly depleted to slightly enriched. Compared with MORB, low-K tholeiites are enriched in large ion lithophile elements (LILE) and depleted in HFSE with high and variable $\varepsilon \mathrm{Nd}(\mathrm{T})$ values (e.g., +4.6 to +8.0 ; Brouxel et al. 1987). The Baiyin mafic volcanic rocks have relatively enriched LREE and low $\varepsilon \mathrm{Nd}(\mathrm{T})$ values, distinctly different from those formed in intraoceanic arcs.

Basalts in incipient back-arc basins have geochemical signatures between N-MORB and intraoceanic arcs. For instance, back-arc basin mafic volcanic rocks in the Sumisu area, middle Izu arc (Hochstaedter et al. 1990a, 1990b), are enriched in alkaline and alkaline-earth metals, and slightly depleted in HFSE and REE, with ${ }^{87} \mathrm{Sr} /{ }^{86} \mathrm{Sr}$ ratios of 0.703 and high positive $\varepsilon \mathrm{Nd}(\mathrm{T})$ values ranging from 6.2 to 9.4. These rocks are also significantly different from the Baiyin mafic volcanic rocks, which have high $\left({ }^{87} \mathrm{Sr} /{ }^{86} \mathrm{Sr}\right){ }_{\mathrm{i}}$ ratios but lower $\varepsilon \mathrm{Nd}(\mathrm{T})$ values.

Mafic rocks in mature island arcs and/or active continental margins are generally calc-alkaline in character, enriched in LILE, Th, and LREE, depleted in $\mathrm{Nb}$ and $\mathrm{Ti}$, and with variable $\varepsilon \mathrm{Nd}(\mathrm{T}$ ) values (Pin and Paquette 1997). The Baiyin mafic volcanic rocks are similar to these in many respects, but on

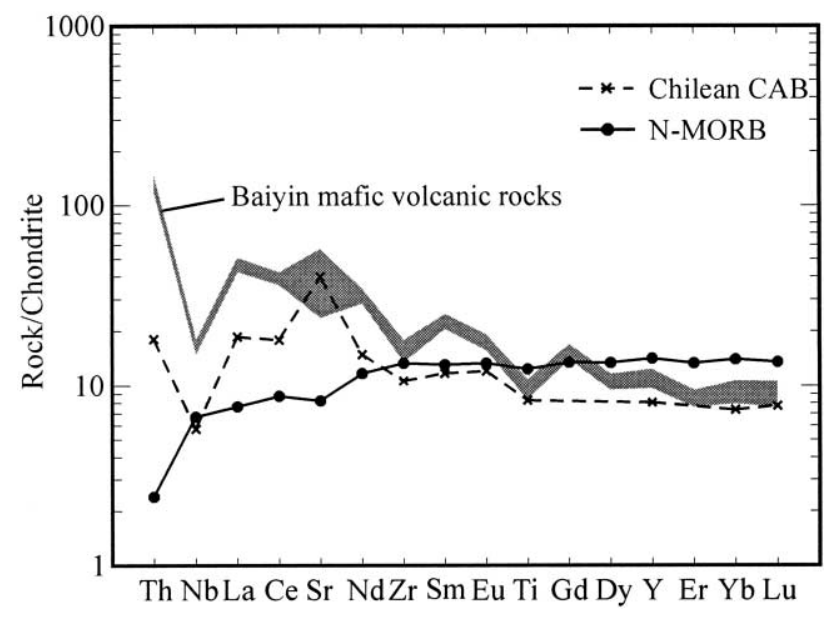

Figure 10. Comparison of the Baiyin mafic rocks, island arc calc-alkaline basalts $(C A B)$ of Chile, and normal midocean ridge basalt $(N-M O R B)$ in terms of chondritenormalized trace element patterns. 


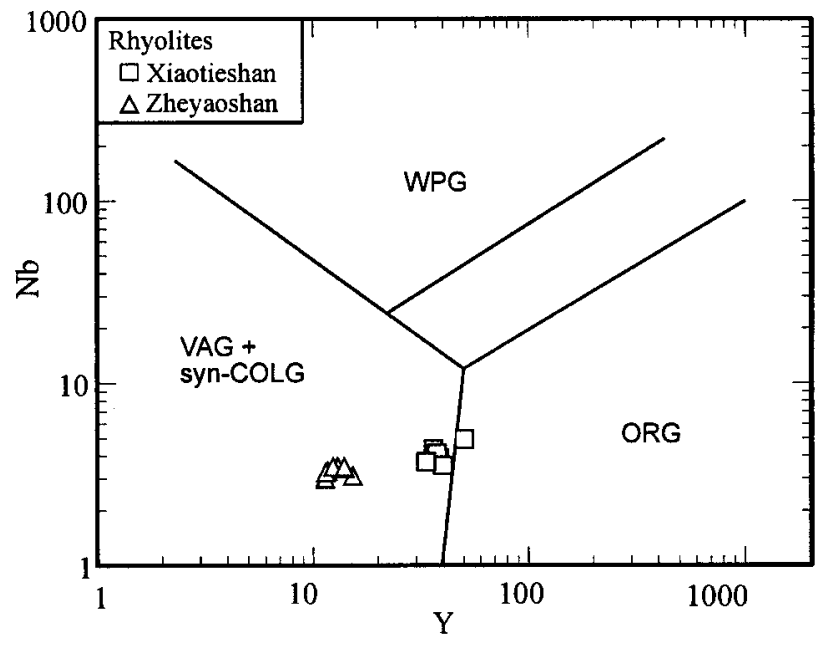

Figure 11. Discrimination diagram of the Baiyin felsic volcanic rocks, NW China (after Pearce et al. 1984). $O R G=$ ocean ridge granites; syn-COLG = synchronouscollision granites; $V A G=$ volcanic arc granites; $W P G=$ within-plate granites.

a $\mathrm{Nb} / \mathrm{Yb}$ versus $\mathrm{Th} / \mathrm{Yb}$ diagram, they all plot in the calc-alkaline continental arc field (fig. 9).

The closest modern analogue for the Baiyin mafic volcanic rocks is the Laguna del Maule volcanic rocks of the southern Chilean Andes, which are relatively enriched in $\mathrm{Th}, \mathrm{Nb}, \mathrm{Sr}$, and LREE, depleted in Ti and HREE, and show negative $\mathrm{Nb}, \mathrm{Zr}$, and $\mathrm{Ti}$ anomalies with high $\mathrm{Th} / \mathrm{Nb}$ ratios $(0.9-1.3$; Frey et al. 1984). The Chilean and Baiyin rocks have similar chondrite-normalized trace element patterns (fig. 10). Based on this comparison, we suggest that Baiyin mafic volcanic rocks formed in a mature island arc or volcanic arc built on young or thin crust on an active continental margin.

The Baiyin felsic volcanic rocks have a calcalkaline affinity and are characterized by low $\mathrm{Y}, \mathrm{Yb}$, $\mathrm{K}, \mathrm{Ti}, \mathrm{Nb}, \mathrm{Sr}$, and $\mathrm{Th}$, relatively high $\mathrm{Th} / \mathrm{Nb}$ ratios $(0.8-1.6)$, low but constant $\left({ }^{87} \mathrm{Sr} /{ }^{86} \mathrm{Sr}\right)_{i}(0.7046-$ $0.7061)$ and high positive $\varepsilon \mathrm{Nd}(\mathrm{T})$ values $(+4.4$ to $+7.7)$. Rhyolites formed by anatexis of continental crust would have a tholeiitic to alkaline affinity, LREE and HFSE enrichment, high Th (e.g., 38 ppm for the Naivasha rhyolites in central Kenya; Davies and MacDonald 1987) and variably negative $\varepsilon \mathrm{Nd}(\mathrm{T})$ values (Lightfoot et al. 1987). Both the Zheyaoshan and Xiaotieshan felsic volcanic rocks have negative $\mathrm{Ti}, \mathrm{Nb}, \mathrm{Sr}$ anomalies (fig. $6 b$ ) and plot in the volcanic arc field (fig. 11). Thus, the Baiyin felsic volcanic rocks also probably formed in a volcanic arc environment rather than from the anatexis of continental crust. On the other hand, the Zheyaoshan and Xiaotieshan felsic volcanic rocks have much lower LREE and HFSE contents and higher positive $\varepsilon \mathrm{Nd}(\mathrm{T})$ values than the Baiyin mafic volcanic rocks. These differences between the Baiyin mafic and felsic volcanic rocks suggest that the felsic volcanic rocks were not derived by fractionation of the mafic magmas. The low $\mathrm{Yb}$ contents of the felsic volcanic rocks $\left(\mathrm{Yb}_{\mathrm{N}}=5.7-8.2\right.$ in Zheyaoshan and $16-26$ in Xiaotieshan) suggest even lower $\mathrm{Yb}$ contents in the parental sources. Thus, if the Baiyin felsic volcanic rocks were derived from mafic melts, these melts would have been much more depleted than those that formed the Baiyin mafic volcanic rocks. However, the lack of intermediate compositions in this area argues against formation of the felsic volcanic rocks by fractional crystallization from a mafic source. We suggest instead that the Baiyin felsic volcanic rocks formed in a volcanic arc setting by partial melting of a mafic parental source of unknown origin.

Implications for the Tectonic Evolution of the North Qilian Orogenic Belt. Volcanic rocks in the volcanic rock belt of the North Qilian Orogenic Belt were previously considered to be an Early Paleozoic
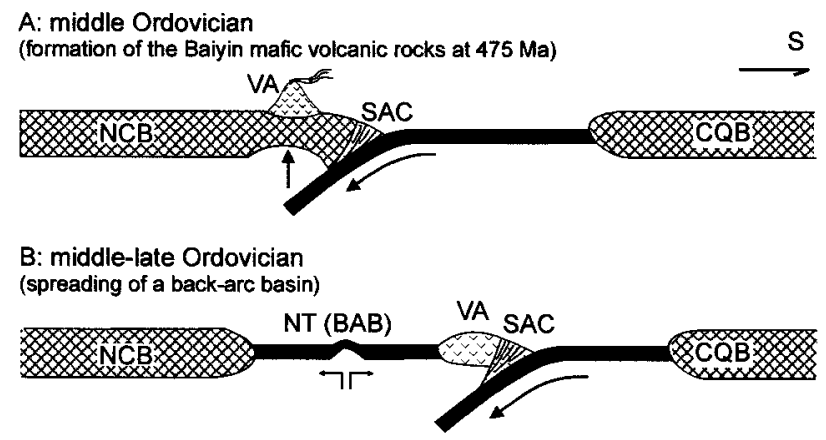

C: middle-late Ordovician

(formation of the Baiyin felsic volcanic rocks at $445 \mathrm{Ma}$ )
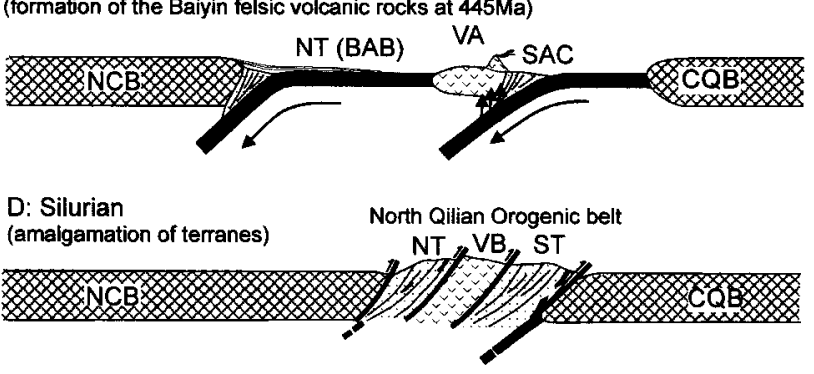

Figure 12. Schematic map showing the tectonic evolution of the North Qilian Orogenic Belt in the Early Paleozoic. $B A B=$ back-arc basin; $C Q B=$ Central Qilian Block; $N C B=$ North China Block; $N T=$ Northern terrane; $S A C=$ subduction-accretionary complex; $S T=$ Southern terrane; $V A=$ volcanic arc; $V B=$ volcanic rock belt. 
continental bimodal volcanic suite (Xia et al. 1996). Thus, Xia et al. (1996) argued that the North Qilian Orogenic Belt evolved from a continental rift into an ocean basin, followed by northward subduction. The belt was therefore considered to have formed from a small oceanic basin (Xia et al. 1996) or even an aulacogen (Ge and Liu 1999). However, our new geochemical data demonstrate that the volcanic rocks formed in a suprasubduction zone environment, probably a mature volcanic arc. The new TIMS and SHRIMP zircon geochronological data suggest that both the Baiyin mafic and felsic volcanic rocks formed in the Ordovician (475-445 Ma), a conclusion supported by two single grain zircon $\mathrm{U}$-Pb ages of $481 \pm 18 \mathrm{Ma}$ and $466 \pm 9 \mathrm{Ma}$ obtained by Zhang et al. (1997) from silicic rocks in the central part of the volcanic rock belt, about $500 \mathrm{~km}$ west of the Baiyin area. Thus, the Baiyin volcanic rocks may represent part of a volcanic rock belt extending $1000 \mathrm{~km}$ in a NW-SE direction. Recognition of this belt as an arc complex rather than a bimodal continental rift assemblage has an important bearing on the tectonic evolution of the North Qilian Orogenic Belt.

We propose a model that involves a volcanic arc formed by northward subduction and amalgamation of different terranes during the Early Paleozoic (fig. 12). In this model, there was an ocean separating the North China Block and the Central Qilian Block in the Middle Ordovician. Northward subduction created an arc along the southern margin of the North China Block, where the Baiyin mafic volcanic rocks formed at $475 \mathrm{Ma}$ (fig. 12A). At the same time, an accretionary wedge, including ophiolites and abyssal sedimentary rocks and lensoid Precambrian metamorphic blocks, was formed above the subduction zone. The presence in the accretionary wedge of eclogites, blueschists, and phegnite schists suggests exhumation of highpressure rocks from depth in the subduction zone. Continued northward subduction eventually resulted in back-arc spreading and the formation of a back-arc basin (fig. 12B, 12C). Partial melting of subducted oceanic rocks in an arc setting produced silicic magmas that formed the Baiyin felsic volcanic rocks at $445 \mathrm{Ma}$ (fig. 12C). The accretionarysubduction assemblage formed the Southern terrane, whereas lavas, pyroclastic rocks, clastic sedimentary rocks, and minor ophiolites in the back-arc basin environment eventually formed the Northern terrane. These two terranes were separated by the volcanic rock belt. Collision of the Central Qilian Block and the North China Block resulted in final amalgamation of the two terranes in the Silurian (fig. 12D).
Our proposed model for the North Qilian Orogenic Belt comprises different tectonic slices juxtaposed by subduction and is consistent with previous geochronological data. For example, Xia et al. (1995) obtained a Sm-Nd isochron age at $454 \pm 4 \mathrm{Ma}$ for the mafic lavas of the Laohushan ophiolite in the Northern terrane, north of Baiyin (fig. 1). In the Qingshuigou area of the Southern terrane, where the HP/ LT metamorphic rocks are best preserved, blueschists have glaucophane with Ar-Ar ages of $489 \pm 16 \mathrm{Ma}$ and $423 \pm 7 \mathrm{Ma}$ (Zhang et al. 1997) and phengite with an age of $448 \pm 11 \mathrm{Ma}$ (Liou et al. 1989), consistent with an age range of 460-440 $\mathrm{Ma}$ reported by $\mathrm{Wu}$ et al. (1993). Thus, formation and emplacement of HP/LT metamorphic rocks are assumed to have occurred at 489-450 Ma and 420 $\mathrm{Ma}$, respectively (Zhang et al. 1997). These ages are in agreement with the subduction and amalgamation envisaged in our model (fig. 12). However, further detailed studies are warranted to fully understand the spatial and temporal relationships between the volcanic rock belt and adjacent terranes.

\section{Conclusions}

1. The Baiyin felsic volcanic rocks formed at 445 $\mathrm{Ma}, 30 \mathrm{~m}$.yr. younger than the spatially associated mafic volcanic rocks. Both the Baiyin felsic and mafic volcanic rocks have chemical signatures of subduction-related arcs and are not part of a continental bimodal association.

2. The mafic volcanic rocks may have formed in a mature island arc or an arc built on thin continental crust at an active continental margin, whereas the felsic volcanic rocks formed in a volcanic arc setting.

3. The volcanic rock belt defines an Ordovician volcanic arc. Thus, formation of the North Qilian Orogenic Belt involved an arc-continent collision.

\section{A C K N O W L E D G M E N T S}

We gratefully acknowledge X.-M. Liu and H.-P. Zhang for assistance with fieldwork; S.-L. Chung of the National Taiwan University for the XRF analyses; and Y. Wang, B. Song, and P. Jian of the Institute of Geology, Chinese Academy of Geosciences, Beijing, for zircon U-Pb SHRIMP analyses. This study was partially supported by a grant from the Research Grant Council of Hong Kong, China (HKU7101/ 01P). We thank two anonymous reviewers for their insightful comments that helped improve an earlier version of this article. 


\section{R E F E R E N C E S C I T E D}

Bian, Q. T. 1989. The geological structure and metallogenetic model of Baiyin Chang mining area. Beijing, Seismic Publishing (in Chinese).

Black, L. P.; Kamo, S. L.; Aleiikoff, J. N.; Davis, D. W.; Korsch, R. L.; and Foudoulis, C. 2003. TEMORA 1: a new zircon standard for Phanerozoic U-Pb geochronology. Chem. Geol. 200:155-170.

Brouxel, M.; Lapierre, H.; and Michard, A. 1987. The deep layers of a Paleozoic arc: geochemistry of the CopleyBlaklala series, northern California. Earth Planet. Sci. Lett. 85:386-400.

Compston, W.; Williams, I. S.; and Kirschvink, J. L. 1992. Zircon U-Pb ages of Early Cambrian time-scale. J. Geol. Soc. 149:171-184.

Cong, B. L., and Wang, Q. C. 1999. The Dabie-Sulu UHP rocks belt: review and prospect. Chinese Sci. Bull. 12: 1074-1081.

Cousens, B. L.; Allan, J. F.; and Gorton, M. P. 1994. Subduction-modified pelagic sediments as the enriched component in back-arc basalts from Japan Sea: Ocean Drilling Program Sites 797 and 794. Contrib. Mineral. Petrol. 117:421-434.

Davies, G. R., and MacDonald, R. 1987. Crustal influences in the petrogenesis of the Naivasha mafic volcanic rocks-comendite complex: combined trace element and Sr-Nd-Pb isotope constraints. J. Petrol. 28: 1009-1031.

Dunphy, J. W., and Ludden, J. N. 1998. Petrological and geochemical characteristics of a Paleoproterozoic magmatic arc (Narsajuaq terrane, Ungava orogen, Canada) and comparisons to Superior Province granitoids. Precamb. Res. 91:109-142.

Frey, F. A.; Gerlach, D. C.; Hickey, R. L.; Escobar, L. L.; and Villavicencio, F. M. 1984. Petrogenesis of the Laguna el Maule volcanic complex, Chile $\left(36^{\circ} \mathrm{S}\right)$. Contrib. Mineral. Petrol. 88:133-149.

Ge, X. H., and Liu, J. L. 1999. Formation and tectonic background of the northern Qilian orogenic belt. Earth Sci. Front. 6:223-230 (in Chinese with English abstract).

Hacker, B. R.; Ratschbacher, L.; Webb, L.; Ireland, T.; Walker, D.; and Dong, S. W. 1998. U-Pb zircon ages constrain the architecture of the ultrahigh-pressure Qinling-Dabie Orogen, China. Earth Planet. Sci. Lett. 161:215-230.

Hemond, C.; Arndt, N. T.; Lichtenstein, U.; Hofmann, A. W.; Oskarsson, N.; and Steinthorsson, S. 1993. The heterogeneous Iceland plume: $\mathrm{Nd}-\mathrm{Sr}-\mathrm{O}$ isotope and trace element constraints. J. Geophys. Res. 98:15,83315,850 .

Hildreth, W.; Halliday, A. N.; and Christiansen, R. L. 1991. Isotopic and chemical evidence concerning the genesis and contamination of mafic volcanic basaltic and rhyolitic magma beneath the Yellowstone Plateau volcanic field. J. Petrol. 32:63-168.

Hochstaedter, A. G.; Gill, J. B.; and Kusakabe, M. $1990 a$.
Volcanism in the Sumisu Rift. I. Element, volatile and stable isotope geochemistry. Earth Planet. Sci. Lett. 100:179-194.

Hochstaedter, A. G.; Gill, J. B.; and Morris, J. 1990b. Volcanism in the Sumisu Rift. II. Subduction and nonsubduction related components. Earth Planet. Sci. Lett. 100:195-209.

Hofmann, A. W., and White, W. M. 1982. Mantle plumes from ancient oceanic crust. Earth Planet. Sci. Lett. 57: 421-436.

Irvine, T. N., and Baragar, W. R. A. 1971. A guide to the chemical classification of the common volcanic rocks. Can. J. Earth Sci. 8:523-548.

Kern, H.; Jin, Z. M.; Gao, S.; Popp, T. T.; and Xu, Z. Q. 2002. Physical properties of ultrahigh-pressure metamorphic rocks from the Sulu terrain, eastern central China: implications for the seismic structure at the Donghai (CCSD) drilling site. Tectonophysics 354: 315-330.

Krogh, T. E. 1973. A low contamination method for decomposition of zircon and the extraction of $\mathrm{U}$ and $\mathrm{Pb}$ for isotopic age determinations. Geochim. Cosmochim. Acta 37:485-494.

Le Maitre, R. W. 1989. A classification of igneous rocks and a glossary of terms: recommendations of the international union of geological sciences sub-commission on the systematics of igneous rocks. Oxford, Blackwell.

Lightfoot, P. C.; Hawkesworth, C. J.; and Sethna, S. F. 1987. Petrogenesis of rhyolithes and trachytes from the Deccan Trap: Sr, $\mathrm{Nd}$ and $\mathrm{Pb}$ isotope and trace element evidence. Contrib. Mineral. Petrol. 95:44-54.

Liou, J. G.; Wang, X. M.; and Colemen, R. G. 1989. Blueschists in major suture zones of China. Tectonics 8:609-619.

Ludwig, K. R. 2001. Users manual for a geochronological toolkit for Microsoft Excel. Berkeley Geochronology Center, Spec. Publ. 1a:59.

Nakamura, N. 1974. Determination of REE, Ba, Fe, Mg, $\mathrm{Na}$ and $\mathrm{K}$ in carbonaceous and ordinary chondrites. Geochim. Cosmochim. Acta 38:757-775.

Pearce, J. A.; Harris, N. B. W.; and Tindle, A. G. 1984. Trace element discrimination diagrams for the tectonic interpretation of granitic rocks. J. Petrol. 25:956983.

Pearce, J. A., and Norry, M. J. 1979. Petrogenetic implications of $\mathrm{Ti}, \mathrm{Zr}, \mathrm{Y}$, and $\mathrm{Nb}$ variations in volcanic rocks. Contrib. Mineral. Petrol. 69:33-47.

Peng, L. G.; Ren, Y. X.; and Li, Z. P. 1995. Mineralization models of copper polymetallic ore deposits in the Baiyin mining field. Beijing, Geological Publishing, p. 2340 (in Chinese).

Pin, C., and Paquette, J. L. 1997. A mantle-derived bimodal suite in the Hercynian belt: $\mathrm{Nd}$ isotope and trace element evidence for a subduction-related rift origin of the Late Devonian Brevenne metavolcanics, 
Massif Central (France). Contrib. Mineral. Petrol. 129: 222-238.

Plank, T., and Langmuir, C. H. 1998. The chemical composition of subducting sediment and its consequences for the crust and mantle. Chem. Geol. 145:325-394.

Qi, L.; Hu, J.; and Gregoire, D. C. 2000. Determination of trace elements in granites by inductively coupled plasma mass spectrometry. Talanta 51:507-513.

Saunders, A. D.; Norry, M. L.; and Tarney, J. 1988. Origin of MORM and chemically-depleted mantle reservoirs: trace element constrains. J. Petrol. (Spec. Lithos Iss.): 415-445.

-1991. Fluid influence on the trace element compositions of subduction zone magmas. Philos. Trans. R. Soc. Lond. A 335:337-392.

Song, S. G. 1997. Tectonic evolution of subduction complex belts in the north Qilian mountains. Adv. Earth Sci. 12:351-365 (in Chinese with English abstract).

Stacey, J. S., and Kramers, J. D. 1975. Approximation of terrestrial lead isotope evolution by a two-stage model. Earth Planet. Sci. Lett. 26:207-221.

Sun, S. S. 1980. Lead isotopic study of young volcanic rocks from mid-ocean ridges, ocean islands and island arcs. Philos. Trans. R. Soc. Lond. A 297:409-445.

Sun, S. S., and McDonough, W. F. 1989. Chemical and isotopic systematics of oceanic basalts: implications for mantle composition and processes. In Saunders, A. D., and Norry, M. J., eds. Magmatism in the ocean basins. Geological Society (London) Spec. Pub. 42: 313-345.

Tapponnier, P.; Meyer, B.; Avouac, J. P.; Peltzer, G.; Gaudemer, Y.; Guo, S. M.; Xiang, H. F.; et al. 1990. Active thrusting and folding in the Qilian Shan, and decoupling between upper crust and mantle in northeastern Tibet. Earth Planet. Sci. Lett. 97:382-403.

Thompson, R. N. 1982. British Tertiary volcanic province. Scot. J. Geol. 18:49-107.

Wang, X. M., and Liou, J. G. 1991. Regional ultrahighpressure coesite-bearing eclogitic terrane in central China: evidence from country rocks, gneiss, marble, and metapelite. Geology 19:933-936.

Weaver, B. L. 1991. The origin of ocean island endmember compositions: trace element and isotopic constraints. Earth Planet. Sci. Lett. 104:381-397.

Williams, I. S., and Claesson, S. 1987. Isotope evidence for the Precambrian province and Caledonian meta- morphism of high grade paragneiss from the Seve Nappes, Scandinavian Caledonides. II. Ion microprobe zircon U-Th-Pb. Contrib. Mineral. Petrol. 97:205-217.

Wilson, M. 1989. Igneous petrogenesis. London, Unwin Hyman, p. 10-100.

Wu, H. Q.; Feng, Y. M.; and Song, S. G. 1993. Metamorphic deformation of blueschist belts and their tectonic implications in north Qilian Mountains, China. J. Metamorph. Geol. 11:523-536.

Xia, L. Q.; Xia, Z. C.; and Xu, X. Y. 1995. Dynamics of tectono-volcano-magmatic evolution from north Qilian mountains, China. Northwest Geosci. 16:1-28 (in Chinese with English abstract).

- 1996. The petrogenesis of marine volcanic rocks from the North Qilian Mountains. Beijng, Geological Publishing, p. 10-64 (in Chinese).

Xu, Z. Q.; Xu, H. F.; and Zhang, J. X. 1994. The Zoulangnanshan Caledonian subductive complex in the northern Qilian mountains and its dynamics. Acta Geol. Sin. 68:1-15 (in Chinese with English abstract).

Xu, Z. Q.; Yang, J. S.; Jiang, M.; and Li, H. B. 1999. Continental subduction and uplifting of the orogenic belts at the margin of the Qinghai-Tibet Plateau. Earth Sci. Front. 6:139-151.

Xu, Z. Q.; Zhang, J. X.; and Xu, H. F. 1997. Main ductile sheared zones and their dynamics in China. Beijing, Geological Publishing, p. 71-108 (in Chinese).

Ye, K.; Cong, B. L.; and Ye, D. N. 2000. The possible subduction of continental material to depths greater than $200 \mathrm{~km}$. Nature 407:734-736.

Yin, A., and Harrison, T. M. 2000. Geologic evolution of the Himalayan-Tibetan orogen. Annu. Rev. Earth Planet. Sci. 28:211-280.

Yin, H. F., and Zhang, K. X. 1998. Evolution and characteristics of the central orogenic belt. Earth Sci. 23: 437-442 (in Chinese with English abstract).

Zhang, G. W., and Liu, X. M. 1998. Some remarks on China central orogenic system. Earth Sci. 23:443-448 (in Chinese with English abstract).

Zhang, J. X.; Xu, Z. Q.; Chen, W.; and Xu, H. F. 1997. A tentative discussion on the ages of the subductionaccretionary complex/volcanic arcs in the middle sector of north Qilian mountain. Acta Petrol. Mineral. 16:112-119 (in Chinese with English abstract).

Zindler, A., and Hart, S. R. 1986. Chemical dynamics. Annu. Rev. Earth Planet. Sci. 14:493-571. 
Copyright of Journal of Geology is the property of University of Chicago Press and its content may not be copied or emailed to multiple sites or posted to a listserv without the copyright holder's express written permission. However, users may print, download, or email articles for individual use. 